\title{
ISOLASI BAKTERIOFAGA ANTI Streptococcus agalactiae DARI IKAN NILA (Oreochromis niloticus)
}

\author{
Angela Mariana Lusiastuti, Uni Purwaningsih, dan Tuti Sumiati \\ Balai Riset Perikanan Budidaya Air Tawar \\ Jl. Raya Sempur No.1, Bogor 16154 \\ E-mail: lusiastuti@yahoo.com
}

(Naskah diterima: 8 April 2010; Disetujui publikasi: 12 Agustus 2010)

\begin{abstract}
ABSTRAK
Infeksi Streptococcus merupakan salah satu penyakit serius pada ikan yang disebabkan oleh bakteri gram positif. Infeksi oleh streptococcus beta-hemolitik paling sering dilaporkan menginfeksi ikan. Di antara streptococci beta-hemolitik, Streptococcus iniae penyebab septicemia, meningoencefalitis, dan kematian pada ikan budidaya. Selain itu, Streptococcus agalactiae juga menyebabkan streptococcosis parah pada ikan nila. Alternatif yang bisa digunakan untuk terapi infeksi streptococcosis adalah dengan penggunaan bakteriofaga yang merupakan virus yang hidup pada bakteri. Tujuan penelitian ini adalah isolasi bakteriofaga $S$. agalactiae sebagai kandidat agen terapi yang memberikan efek protektif melawan infeksi streptococcosis. Faga diisolasi dari Brain Heart Infusion Agar (BHIA) yang sudah ditanami dengan 15 isolat S. iniae dan S. agalactiae. Isolat S. iniae dan S. agalactiae diisolasi dari ikan sakit dengan gejala klinis Streptococcosis. Setelah itu diidentifikasi dengan pewarnaan Gram, tes katalase, pertumbuhan pada agar darah dan API 20 Strep System. Pertumbuhan faga ditunjukkan dengan adanya zona lisis pada tempat yang ditetesi dengan sampel cairan usus dari ikan nila sehat. Faga yang tumbuh lalu dikoleksi secara steril, disentrifus dan supernatannya difiltrasi dengan membran filter $0,45 \mu \mathrm{m}$ dan disimpan pada suhu $4^{\circ} \mathrm{C}$. Dari 15 isolat S. iniae dan S. agalactiae hanya satu isolat yaitu PSaT-18 yang menunjukkan zona lisis seperti yang ditunjukkan pada cawan petri isolat kontrol $S$. iniae. Zona lisis tersebut timbul akibat adanya faga yang memberikan proteksi terhadap S. iniae dan S. agalactiae. Zona lisis yang tidak jernih disebabkan konsentrasi faga yang terlalu rendah akibat dilakukan pengenceran pada proses filtrasi. Faga yang diperoleh selanjutnya akan dilakukan uji in vitro dan in vivo untuk mengetahui efektivitasnya.
\end{abstract}

KATA KUNCl: S. iniae, S. agalactiae, bakteriofaga, ikan nila

ABSTRACT: Isolation Streptococcus agalactiae bacteriophage from Oreochromis niloticus. By: Angela Mariana Lusiastuti, Uni Purwaningsih, and Tuti Sumiati

Streptococcal infection is a serious disease in fish caused by gram positive bacteria. The causative agent is Streptococcus $\beta$-hemolytic. Streptococcus iniae, a $\beta$-hemolytic bacterium is the main causative agent of septicemia, meningoencephalitis, and fish mortality. Moreover, the other causative agent is S. agalactiae. Bacteriophages which are viruses that live on bacteria can be selected and used as therapy for Streptococcosis. The aim of this research is to isolate bacteriophage of S. agalactiae as therapeutic agent candidate giving protecting effect for Streptococcosis. Phages was isolated from Brain Heart Infusion Agar (BHIA) were obtained from cultures of $\mathbf{S}$. iniae and $S$. agalactiae. Strains $S$. iniae and $S$. agalactiae were isolated from 
Streptococcosis fish. The predominant types of colonies were subcultured and subjected to biochemical and physiological tests such as Gram staining, catalase test, hemolytic activity in blood agar and API 20 Strep System. Phages were isolated by using a double agar layer method. A zona lysis with plaques was removed from the plate, centrifuged and the supernatant was filtered through a $0.45 \mu \mathrm{m}$ membrane filter and stored at $4^{\circ} \mathrm{C}$. From 15 isolates of S. iniae and S. agalactiae, only one isolate PSaT-18 showed lysis zone. The lysis zone developed because the phages give protection to $\mathrm{S}$. agalactiae. The lysis zone is not clear because the phage concentration is too low and the dilution in filtration process is too high. Later, these phages were used for invitro and invivo test.

\section{KEYWORDS: S. iniae, S. agalactiae, bacteriophages, Oreochromis niloticus}

\section{PENDAHULUAN}

Ikan nila (Oreochromis niloticus) merupakan ikan budidaya yang menguntungkan tetapi serangan penyakit bakterial streptococcosis menyebabkan kerugian sekitar 30\%-40\%. Salah satu jenis bakteri streptococcus yang menimbulkan penyakit adalah S. iniae. Tetapi, Supriyadi et al. (2005) dan Lusiastuti et al. (2008) mengisolasi jenis streptococcus lain yang bersifat patogen selain $S$. iniae yaitu $S$. agalactiae. Nomoto et al. (2004) menemukan adanya infeksi campuran antara $S$. iniae, Lactococcus garviae dan S. dysgalactiae, sedangkan Evans et al. (2006) menemukan infeksi ganda antara $S$. agalactiae dan $L$. garviae pada dolfin. Jika sudah terjadi infeksi bakteri, antibiotika biasanya sebagai obat pilihan untuk terapi. Munculnya sifat resistensi mikroba terhadap antibiotika dan bahayanya residu antibiotika yang berdampak negatif bagi masyarakat menyebabkan beberapa jenis antibiotika broad spectrum dilarang beredar dan dipergunakan untuk obat ikan (Keputusan Menteri Kelautan dan Perikanan KepMen No. 26/MENKP/2002 tentang pelarangan penggunaan antibiotik dan KepMen No. 20/ MENKP/2003 tentang klasifikasi obat ikan).

Alternatif yang bisa digunakan untuk terapi infeksi streptococcosis adalah dengan penggunaan bakteriofaga yang merupakan virus yang hidup pada bakteri. Bakteriofaga secara teoritis dapat sebagai terapi penyakit infeksius, tetapi hanya sedikit yang melaporkan potensinya sebagai agen kontrol biologis pada penyakit yang terjadi di alam. Faga dari beberapa bakteri patogen pada ikan, seperti Aeromonas salmonicida (Rodgers et al., 1981), A. hydrophila (Merino et al., 1990), dan Yersinia ruckeri (Stevenson \& Airdrie, 1984) telah dilaporkan tetapi tidak ada tindak lanjut setelahnya untuk digunakan sebagai agen kontrol infeksi bakteri pada ikan. Penelitian Wu et al. (1981) dan Wu \& Chao (1982) pertamakali menjelaskan aplikasi faga sebagai kontrol biologis patogen pada ikan (A. hydrophila dan Edwardsiella tarda). Setelah itu, penelitian secara kontinu oleh Smith \& Huggins (1982) di mana faga berhasil digunakan sebagai terapi infeksi $E$. coli yang menyerang tubuh dan otak tikus, diare E. coli pada anak sapi, kambing, dan babi (Smith et al., 1987) dan Barrow et al. (1998) tentang pencegahan infeksi E. coli pada unggas. Nakai \& Park (2002) telah melakukan terapi faga spesifik dari L. garvieae melalui intra peritoneal dan per oral secara eksperimental pada ikan ekor kuning dan pada infeksi Pseudomonas plecoglossicida yang merupakan bakteri penyebab haemorrhagic ascites pada ikan Ayu.

Dibandingkan dengan antibiotika kimiawi, bakteriofaga mempunyai beberapa keuntungan (Lorch, 1999) yaitu: (1) dampaknya terbatas: tidak seperti antibiotik, bakteriofaga dapat bereplikasi sendiri secara eksponensial selama ada bakteri spesifik di sekitarnya. Menurunnya jumlah bakteri akan menurunkan pula jumlah faga dan secara perlahan faga akan menghilang dari ikan sakit dan lingkungannya. Faga baik diberikan pada dosis tunggal; (2) perkembangan resistensi terbatas: bakteri dapat resisten terhadap faga. Tetapi karena faga mempunyai daya mutasi dan tingkat replikasi yang tinggi, faga beradaptasi dan tidak bersaing dengan bakteri; (3) target spesifik: terapi dengan antibiotika sering menyebabkan ketidakseimbangan flora bakteri dan menimbulkan munculnya infeksi sekunder seperti Pseudomonas sp. atau Clostridium difficile yang menyebabkan infeksi dan diare pada kolon. Di lain pihak, target sasaran bakteriofaga pada bakteri yang spesifik saja sehingga gangguan pada flora 
usus menjadi lebih ringan (Lorch, 1999). Tujuan penelitian ini adalah mengisolasi bakteriofaga dari ikan yang terkena streptococcosis untuk diseleksi sebagai kandidat agen kontrol biologis terhadap Streptococcus sp.

\section{BAHAN DAN METODE}

\section{Bakteri}

Sebanyak 15 isolat bakteri yang berperan sebagai organisme indikator yaitu S. iniae ( 5 isolat) dan S. agalactiae (7 isolat) dan 3 isolat diduga $S$. dysgalactiae dan L. garviae digunakan dalam penelitian ini. Isolat-isolat tersebut berasal dari ikan sakit dengan gejala Streptococcosis yang berasal dari Jawa Tengah dan Jawa Barat. Isolat yang berasal dari otak, hati, limpa, dan ginjal dipelihara dalam Brain Heart Infusion Agar (BHIA) dan koloni yang tumbuh dikarakterisasi secara kimiawi.

\section{Isolasi dan Karakterisasi Streptococcus}

Cairan otak, hati, limpa, dan ginjal dari ikan sakit dengan gejala streptococcosis diinokulasi pada BHIA dan diinkubasi pada $25^{\circ} \mathrm{C}$ selama 48 jam. Koloni yang tumbuh dengan karakteristik koloni kecil, halus, dan tidak berwarna dilakukan pengujian selanjutnya meliputi: pewarnaan Gram, produksi katalase, tes tolerans garam $(6,5 \%$ $\mathrm{NaCl}$ ), aktivitas hemolitik pada agar darah, tes API 20 STREP System, dan sensitivitas antibiotika pada Mueller Hinton Agar.

Organ yang diduga terinfeksi juga dilakukan pemeriksaan patologi anatomi baik secara makroskopis maupun mikroskopis (histopatologis).

\section{Isolasi faga dan Plaque Forming Unit (PFU) Assay}

Faga diisolasi dari ikan sehat, ikan sakit, dan air kolam dari Jawa Tengah dan Jawa Barat. Organ yang digunakan berupa ginjal, hati, dan otak (pooling) serta isi usus dihomogenisasi dengan PBS dan disentrifus $3.000 \times$ g selama 10 menit. Satu $\mathrm{mL}$ supernatan diinokulasi masing-masing dalam $100 \mathrm{~mL}$ BHIB yang sudah disuplementasi dengan isolat bakteri S. iniae, S. agalactiae, dan isolat Streptococcus lain (organisme indikator). Untuk sampel air, 100 $\mathrm{mL}$ air kolam difilter melalui $0,45 \mu \mathrm{m}$ membran filter dan dicampur dengan $100 \mathrm{~mL}$ double strength BHIB berisi organisme indikator. Setelah 48 jam ditumbuhkan dan diaduk perlahan pada suhu $25^{\circ} \mathrm{C}$, kultur disentrifus dan di-filter, supernatantnya dilakukan Plaque Forming Unit Assay (PFU).

\section{HASIL DAN BAHASAN}

\section{Karakteristik Isolat Organisme Indikator}

Bentuk koloni pada $S$. iniae dan $S$. agalactiae hampir sama. Koloni sangat halus, bentuknya kecil berdiameter $\pm 1 \mathrm{~mm}$, tampak seragam dan tidak berwarna (colorless, non pigmented). Jika koloni tumbuh banyak, berkumpul menjadi satu dan tebal maka cenderung berwarna keputihan. Streptococcus dysgalactiae dan L. garviae yang juga digunakan sebagai organisme indikator mempunyai bentuk koloni yang lebih besar dan berwarna kekuningan. Baik S. iniae, S. agalactiae, dan Streptococcus yang lain menghasilkan reaksi terhadap API 20 STREP Sistem yang hampir sama hanya berbeda dengan hasil tes Voges Proskauer (VP). Streptococcus iniae dan S. faecalis hasil tes VP negatif sedangkan $S$. agalactiae positif. Menurut Evans et al. (2006), tes VP isolat $S$. agalactiae dari otot dolfin betina dewasa menunjukkan hasil negatif menggunakan metode konvensional sedangkan dengan API Rapid ID 32 test kit memberikan hasil yang positif. Streptococcus iniae dan S. agalactiae tidak toleran terhadap kadar garam 6,5\% dan tes katalasenya negatif. Perbedaan yang tampak pada agar darah, S. iniae adalah beta hemolitik dengan terbentuknya zona lisis yang jernih dan tidak berwarna (colorless) sedangkan S. agalactiae adalah alfa hemolitik dikarakterisasi oleh zona lisis yang berwarna kehijauan. Jika pada satu cawan petri tumbuh dua jenis koloni yaitu S. iniae dan S. agalactiae maka S. agalactiae akan tumbuh dominan dan menekan pertumbuhan S. iniae pada hari kedua inkubasi.

Streptococcus agalactiae patogen pada ikan dan menyebabkan perubahan klinis dan histopatologis, termasuk exophthalmia, meningoencephalitis, vakuolisasi dan nekrosis sel-sel hati serta nekrosis dan kongesti limpa. Menurut Lindahl et al. (2005), S. agalactiae juga patogen pada mamalia termasuk manusia dan sapi. Gambar 1 menunjukkan kerusakan pada hati dan limpa akibat streptococcosis. 

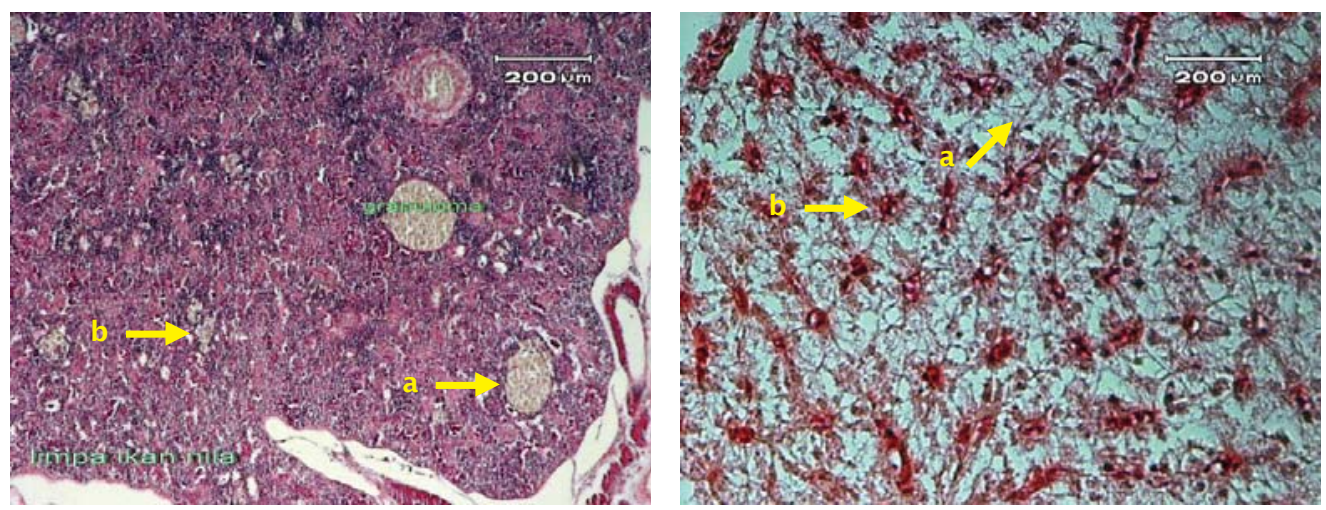

a. Vakuolisasi dan nekrosis sel-sel hati (Vacuolisation and necrosis of liver cells)

b. Nekrosis dan kongesti limpa (Necrosis and congestion of spleen cells)

Gambar 1. Kerusakan pada sel hati dan limpa

Figure 1. Necrosis of liver and spleen cells

Pada parensim hati sel-sel hepatosit menunjukkan atrofi, pembengkakan berwarna keabuan (cloudy swelling), vakuolisasi dan nekrosis. Vakuolisasi terbentuk sebagai akibat gangguan mekanisme penyerapan sodium sedangkan nekrosis terjadi karena aktivitas toksin dan enzim yang dihasilkan oleh Streptococcus sp. Kongesti (pembendungan pembuluh darah) terjadi akibat proses peradangan dan kerusakan dari organ. Nampak adanya endapan pigmen hemosiderin dan granulomatosis pada hati. Ada tiga tahapan kerusakan pada hati, tahap awal ditandai dengan inflamasi dan hiperemi (kemerahan), biasanya infeksi bersifat akut. Tahap selanjutnya mulai terjadi gangguan metabolisme dengan diawali munculnya degenerasi lemak, hati tampak pucat dan rapuh pada pemeriksaan eksternal.

Pada limpa tampak adanya inflamasi granulomatous menunjukkan produksi granuloma pada jaringan yang terinfeksi. Di dalam granuloma yang berwarna coklat keabu-abuan tersebut terdapat eksudat inflamasi dan bakteri yang terdapat dalam kondisi tidak terbentuk (amorphous matter). Beberapa kapiler tampak adanya eritrosit.

\section{Isolasi Bakteriofaga dari S. agalactiae}

Pada Tabel 1 menyajikan hasil isolasi bakteriofaga terhadap tiga jenis organisme indikator yaitu S. iniae dan S. agalactiae. Dua jenis faga dapat diisolasi dari 15 sampel dengan tiga kondisi yaitu ikan sakit secara klinis streptococosis, ikan subklinis dan air kolam dan dinamai PSaT-1 dan PSaT-2. Zona lisis dari PSaT-1 tidak sejernih zona lisis yang dibentuk oleh PSaT-2. PSaT-2 menunjukkan zona lisis yang lebih tajam. Zona lisis terbentuk setelah 24 jam pada inkubasi $28^{\circ} \mathrm{C}$. Organisme indikator yang digunakan oleh masing-masing faga berbeda, untuk PSaT-1 menggunakan $S$. iniae dan PSaT-2 dengan S. agalactiae. Tetapi jenis sampel dari keduanya sama yaitu dari isi usus ikan sublinis. Hal ini menunjukkan beberapa kemungkinan bahwa keduanya adalah faga yang sama dan spesifik terhadap $S$. agalactiae tetapi bersifat strain spesifik karena masih mampu melisis S. iniae.

Faga sulit diisolasi dari ikan sakit karena mikroba penyebabnya tumbuh dominan. Pada ikan yang sehat, fagapun sulit diisolasi. Menurut Lorch (1999), jika jumlah bakteri patogen menurun maka fagapun secara perlahan akan tereliminasi dan menghilang dari tubuh ikan dan lingkungannya. Pada ikan tampak sehat atau disebut dalam kondisi subklinis, faga dapat diisolasi. Pada kondisi subklinis, pertumbuhan faga dan mikroba patogen penyebabnya dalam keadaan seimbang atau jumlah faga lebih banyak dibanding mikroba penyebabnya. Ikan masih tampak sehat secara klinis tetapi mikroba patogen mulai berkembang biak. Ikan subklinis yang digunakan sebagai sampel masih aktif berenang dan tampak sehat hanya ada sedikit lecet-lecet pada kulitnya. Kondisi organnya juga tampak normal tidak ditemukan adanya 


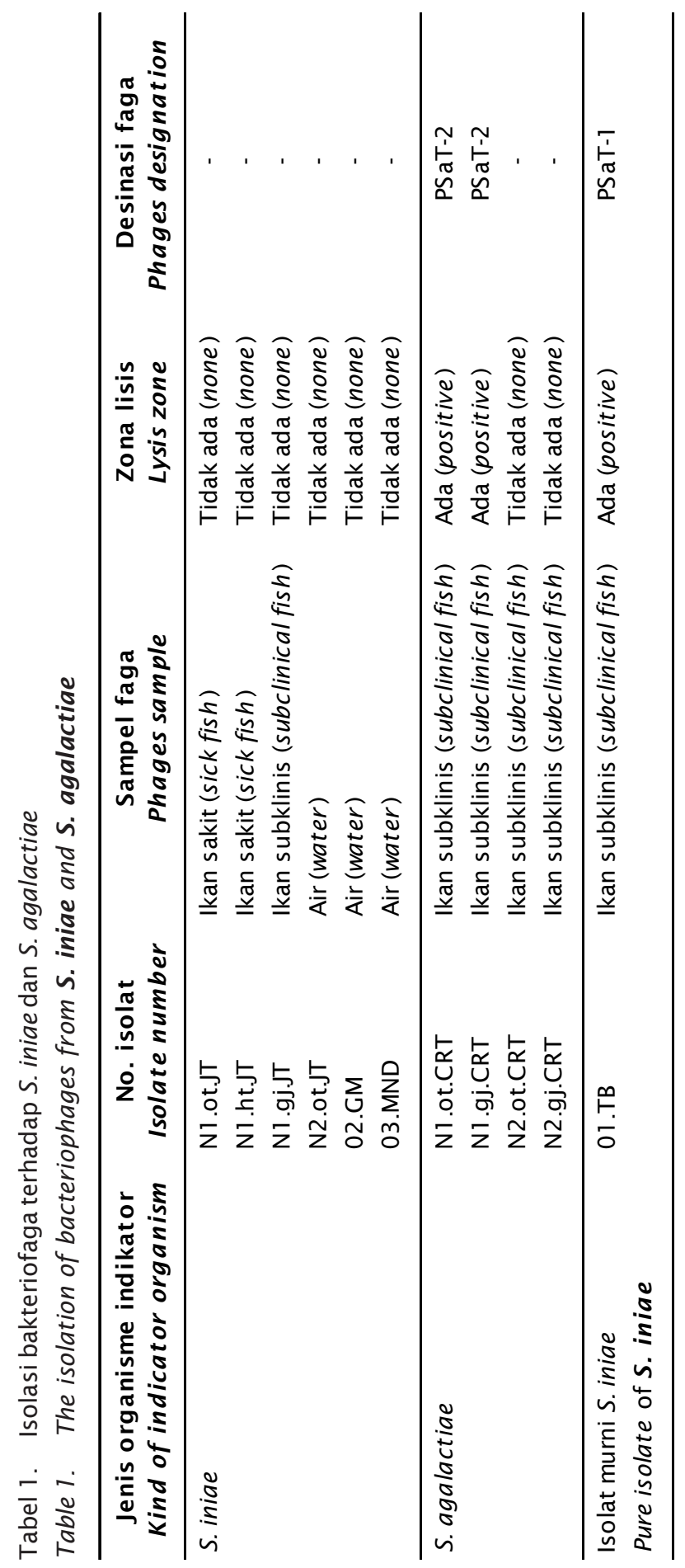



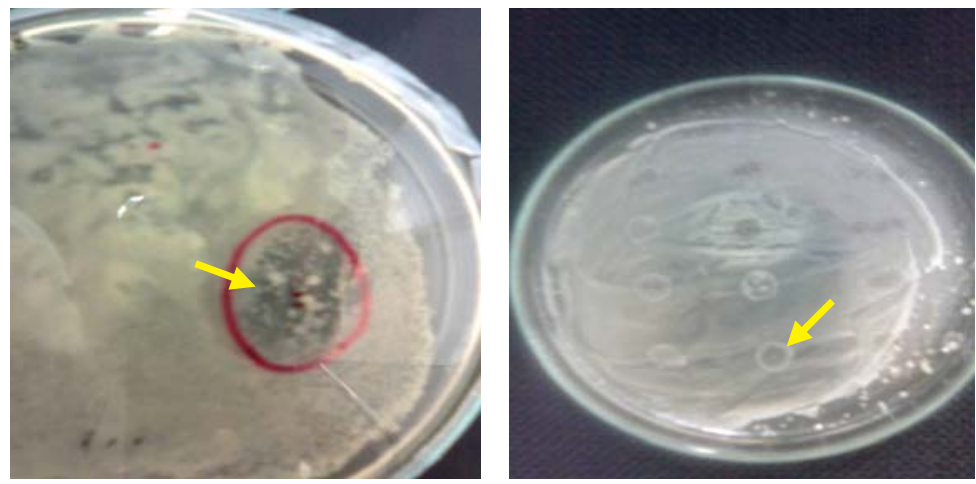

Gambar 2. Faga yang membentuk zona lisis terhadap S. agalactiae Figure 2. The lysis zone of phages from S. agalactiae

kelainan secara makroskopis. Di bawah ini dua jenis faga yang dapat tumbuh dengan membentuk zona lisis terhadap S. agalactiae.

Zona lisis yang tampak pada Gambar 2 tidak jernih disebabkan konsentrasi faga yang rendah dan kemungkinan akibat dilakukannya pengenceran pada waktu proses filtrasi menggunakan broth sehingga faga kurang kuat membentuk zona lisis.

\section{KESIMPULAN}

Bakteriofaga telah dapat diisolasi dari $S$. agalactiae dan spesifik terhadap S. agalactiae tetapi masih membentuk zona lisis terhadap S. iniae.

\section{DAFTAR ACUAN}

Barrow, P., Lovell, M., \& Jr Berchieri, A. 1998. Use of lytic bacteriophage for control of experimental Escherichia coli septicemia and meningitis in chickens and calves. Clin. Diag. Lab. Immunol., 5: 294-298.

Evans, J.J., Pasnik, D.J., Klesius, P.H., \& Al-Ablani, S. 2006. First report of Streptococcus agalactiae and Lactococcus garviae from a wild bottlenose dolphin (Tursiops truncatus). J. of Wildlife Dis., 42(3): 561-569.

Lindahl, G., Stalhammar-Carlemalm, M., \& Areschoug, T. 2005. Surface proteins of Streptococcus agalactiae and related proteins in other bacterial pathogens. Clinical Microbiology, 18: 102-127.

Lorch, A. 1999. Bacteriophages: An Alternative to Antibiotics? Ausbiotech, 9(5): 1-5.

Lusiastuti, A.M., Supriyadi, H., Aryati, Y., Mufidah, T., Gardenia, L., \& Sumiati, T. 2008. Studi kasus: Streptococcosis pada ikan gurame disebabkan oleh Streptococcus iniae dan Streptococcus agalactiae. Prosiding Seminar Gelar Teknologi di Manado tanggal 2-3 Mei 2008, $8 \mathrm{hlm}$.

Merino, S., Camprubi, \& Tomas, JM. 1990. Isolation and characterization of bacteriophage PM2 from Aeromonas hydrophila. FEMS Microbiol. Lett., 68: 239-244.

Nakai, T. \& Park, S.C. 2002. Bacteriophage therapy of infectious diseases in aquaculture. Res. In Microbiol., 153(2002): 13-18.

Nomoto, R., Munasinghe, L.I., Jin, D.H., Shimahara, Y., Yasuda, H., Nakamura, A., Misawa, N., Itami, T., \& Yoshida, T. 2004. Lancefield group C Streptococcus dysgalactiae infection responsible for fish mortalitas in Japan. J. Fish Dis., 27: 679-686.

Rodgers, C.J., Pringle, J.H., McCarthy, D.H., \& Austin, B. 1981. Quantitative and qualitative studies of Aeromonas salmonicida bacteriophage. J. Gen. Microbiol., 125: 335345.

Smith, H.W. \& Huggins, M.B. 1982. Successful treatment of experimental Escherichia coli infections in mice using phage: Its general superiority over antibiotics. J. Gen. Microbiol., 128: 307-318.

Smith, H.W., Huggins, M.B., \& Shaw, K.M. 1987. The control of experimental Escherichia coli diarrhoeae in calves by means of bacteriophages. J. Gen. Microbiol., 133: 1,1111,126 .

Supriyadi, H., Widiyati, A., Sunarto, A., \& Prihadi, T.H. 2005. Keragaan penyakit bakterial ikan nila (O. niloticus), pada KJA di lokasi berbeda. J. Pen. Perik. Indonesia, 11 (7): 35-46. 
Stevenson, R.M.V. \& Airdrie, D.W. 1984. Isolation of Yersinia ruckeri bacteriopahges. Appl. Environ. Microbiol., 47: 1,201-1,205.

Wu, J.L. \& Chao, W.J. 1982. Isolation and application of new bacteriophage ET-1 which infect Edwardsiella tarda the pathogen of edwardsiellosis. CAPD Fisheries Series No. 8, Reports on Fish Disease Res. (Taiwan), 4: 8-17.
Wu, J.L., Lin, H.M., Jan, L., Hsu, Y.L., \& Chang, L.H. 1981. Biological control of fish bacterial pathogen Aeromonas hydrophila by bacteriophage AH1. Fish Pathol., 15: 271-276.

Yuasa, K., Kitancharoen, N., Kataoka, Y., \& AlMurbaty, F.A. 1999. Streptococcus iniae, the causative agent of mass mortality in rabbitfish Siganus canaliculatus in bahrain. J. Aquat. Anim Health, 11: 87-93. 